\title{
KESAN PERANG KOREA KE ATAS TANAH MELAYU, 1950-1953: SATU TINJAUAN UMUM
}

\section{Ho Hui Ling}

\section{Pengenalan}

The economic variable has long been recognised as salient to any study why men rebel. Similarly, the economic variable is a necessary consideration when analysing the course and out come of an insurgency. It can be crucial to the understanding why rebels succeed or fail. ${ }^{1}$

Petikan di atas yang dikutip daripada tulisan Richard Stubbs bertajuk Counter-Insurgency and the Economic Factor: The Impact of the Korean War Prices Boom on the Malayan Emergency menunjukkan bahawa faktor ekonomi penting dalam menentukan kejayaan atau kegagalan usaha kerajaan dalam mematahkan sesuatu pemberontakan. Dalam kes di Tanah Melayu, kerajaan British telah menyumbangkan sejumlah $\$ 25$ juta kepada perbelanjaan Tanah Melayu pada tahun 1950. Namun demikian, pada Mei 1950, Pesuruhjaya Tinggi Henry Gurney telah menyuarakan kebimbangan tentang kekeringan rizab kerajaan Tanah Melayu menjelang akhir tahun 1950 memandangkan negara sedang berusaha mengatur langkah untuk menghapuskan pengganas komunis. Bagaimanapun, Perang Korea yang meletus pada Jun 1950 telah memberi sinar harapan kepada usaha kerajaan dalam menangani 
ancaman komunis. Walaupun Perang Korea hanya berlanjutan dalam masa tiga tahun sahaja, tetapi kesan ekonomi yang dicetuskan oleh perang tersebut telah meletakkan asas kejayaan kepada usaha kerajaan menentang pengganasan komunis di Tanah Melayu.

\section{Perang Korea dan Suasana di Tanah Melayu}

Disebabkan kedudukan yang strategik, Korea telah menjadi medan persaingan beberapa kuasa besar dalam menegakkan kekuasaan mereka di situ. China, Rusia dan Jepun telah berjaya menegakkan kekuasaan mereka di kawasan ini. Berikutan dengan kemerosotan Dinasti Yi yang diasaskan pada tahun $1392,{ }^{2}$ Korea ditakluki oleh Jepun pada tahun 1910. Semasa Perang Dunia Kedua, tentera Rusia berperang dengan tentera Jepun di bahagian utara Korea dan tentera Amerika Syarikat pula bertahan di bahagian selatan. Pihak Jepun menyerah diri kepada tentera Rusia di bahagian utara Korea dan tentera Amerika di bahagian selatan Korea menjelang akhir Perang Dunia Kedua setelah kota Hiroshima dan Nagasaki dimusnahkan oleh bom atom pihak Berikat. Berikutnya, kuasa politik dan ketenteraan Korea dibahagikan di antara dua kuasa, iaitu Amerika Syarikat mengambil alih pentadbiran di bahagian selatan dan Rusia di bahagian utara. Garis lintang $38^{\circ}$ menjadi garis pemisah antara dua bahagian Korea dan sempadan politik yang membahagikan kuasa Rusia dengan Amerika. Dengan itu, Korea Utara ditadbir oleh golongan komunis di bawah pimpinan Kim II-sung ${ }^{3}$ dan pentadbiran tentera Amerika Syarikat berkuasa di bahagian selatan sehingga kerajaan baru (Republik Korea) dibentuk pada 15 Ogos 1948 di bawah pimpinan Syngman Rhee. Dengan itu, pentadbiran Korea telah dibahagikan di antara golongan komunis di bahagian utara dan golongan nasionalis di bahagian selatan. Percubaan yang dilakukan oleh rejim komunis di Korea Utara untuk menggabungkan semula negara itu dengan cara ketenteraan telah membawa kepada meletusnya Perang Korea pada 25 Jun $1950 .^{4}$ Pada 25 Jun 1950, North Korean People's Army (tentera komunis) melintasi sempadan pemisah (garis lintang $38^{\circ}$ ) antara dua kuasa, Rusia dan Amerika dan mencerobohi Korea Selatan. Bangsa-Bangsa Bersatu mengarahkan tentera komunis Korea Utara supaya mengundurkan diri 
daripada Korea Selatan tetapi pihak Korea Utara enggan berbuat demikian. Berikutnya, tentera Amerika Syarikat di bawah pimpinan Jeneral Douglas MacArthur bertindak mempertahankan Korea Selatan daripada pencerobohan tentera Korea Utara. Apabila ini berlaku, Komunis China campur tangan membantu tentera Korea Utara menentang tentera Amerika Syarikat. Dengan itu, bermula Perang Korea yang berlanjutan selama tiga tahun. Perang itu berakhir berikutan penandatanganan perjanjian perletakan senjata di antara kerajaan Korea Utara dengan Korea Selatan pada 27 Julai $1953 .^{5}$

Sementara itu, Tanah Melayu pada tempoh tersebut sedang bergiat melawan pengganasan komunis. Komunis telah menimbulkan banyak kekacauan di Tanah Melayu sehingga undang-undang darurat diisytiharkan di Tanah Melayu pada 18 Jun 1948 oleh Pesuruhjaya Tinggi British Edward Gent. ${ }^{6}$ Walaupun undang-undang darurat dikuatkuasakan, kegiatan komunis masih berleluasa di seluruh Tanah Melayu. Setiap hari terdapat kejadian keganasan komunis yang dilaporkan di merata tempat di Tanah Melayu. Ini meliputi pembunuhan, penculikan, memeras ugut, merosakkan harta benda awam, merosakkan pokok-pokok getah dan lombong timah. Sejak darurat diisytiharkan sehingga 31 Disember 1949, seramai 655 orang awam telah menjadi mangsa keganasan komunis. Sementara itu, dalam tempoh masa yang sama, seramai 173 orang awam dicederakan dan 98 orang hilang. Dalam tempoh yang sama, 67 polis tetap terbunuh dan 91 polis tetap mengalami kecederaan. ${ }^{7}$ Pada bulan November 1950 sahaja, terdapat seramai 66 orang awam yang dibunuh oleh pengganas komunis. ${ }^{8}$ Sehingga lewat Jun 1952, seramai 2,070 orang awam telah menjadi mangsa keganasan komunis. ${ }^{9}$ Dalam pada itu, pada tahun 1950 , bangunan yang dirosakkan oleh pengganas komunis di estet termasuk rumah asap, pejabat, kilang getah, tempat tinggal pekerja bernilai hampir $\$ 51 / 2$ juta dan lebih kurang 300,000 pokok getah ditakik oleh komunis. ${ }^{10}$ Kenderaan yang dibinasakan oleh pengganas komunis

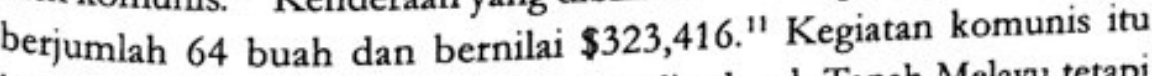
bukan sahaja menimbulkan huru-hara di seluruh Tanah Melayu tetapi juga menjejaskan kepentingan ekonomi British khasnya dan pentadbiran British di Tanah Melayu. Ini memandangkan Tanah Melayu adalah tempat pelaburan dan perusahaan yang penting bagi British. 
Malahan akhbar Nanyang Siang Pau bertarikh 22 September 1948, melaporkan bahawa "pertumbuhan ekonomi di Tanah Melayu adalah punca perkembangan ekonomi British; 'vitamin' kepada kehidupan penduduknya." ${ }^{12}$ Kenyataan ini bermakna ekonomi Tanah Melayu adalah penting kepada kemakmuran ekonomi Britain. Kepentingan industri getah Tanah Melayu misalnya, kepada kedudukan ekonomi Britain dinyatakan oleh Nicholas J. White seperti berikut:

Malaya's rubber production ... produces dollars to an amount that exceeds in total value all domestic exports from Britain to the US . . . if, for any reason, the operation of the great rubber industry are interrupted or seriously impaired, Britain's dollar situation would be rendered more acute than ever. This country would then have less food, less clothes, and there would be fewer dollars with which to buy raw materials - and that would mean unemployment. All of us are thus deeply concerned in what is happening in Malaya. ${ }^{13}$

Dengan itu, kerajaan bertindak mengambil berbagai langkah untuk menangani kegiatan pengganas komunis demi memelihara kepentingan mereka di Tanah Melayu. Antaranya, mengemaskinikan pasukan keselamatan, menguatkuasakan peraturan pendaftaran kebangsaan dan penggunaan kad pengenalan, ganjaran kepada penduduk yang memberi maklumat berkaitan komunis, mengedarkan risalah tawaran menyerah diri kepada pengganas komunis, Kempen Bulan Rakyat Melawan Penjahat, penubuhan unit Home Guard, kawalan makanan dan rancangan penempatan semula. Sebagai contohnya, berikutan dengan tawaran menyerah diri yang diambil oleh Henry Gurney pada 6 seluruh negara dan publisiti yang hebat mengenainya disebarkan di akhbar tempatan. Kejayaan tawaran itukukan melalui berbagai penyerahan diri 116 pengganas di antara itu dapat dilihat melalui 1949. ${ }^{14}$ Begitu juga untuk menjayakan Keptember hingga Disember Penjahat, publisiti yang luas dilakukan men Bulan Rakyat Melawan 170,000 poster, $4,100,000$ risalah dilakukan melalui radio dan akhbar; diedarkan. ${ }^{15}$ Untuk menjayakan lanta 40,000 buku kecil dicetak dan kerajaan ini melibatkan kos 
yang tinggi. Selepas keganasan komunis mencapai kemuncak dengan pembunuhan Pesuruhjaya Tinggi British di Tanah Melayu, Henry Gurney pada 6 Oktober 1951, usaha yang lebih giat diambil oleh Pesuruhjaya Tinggi British yang baru, Jeneral Templer untuk menangani kegiatan komunis. Ini termasuklah memperkuatkan kerja perisikan, memperluaskan kanun kewarganegaraan untuk meliputi kaum bukan Melayu supaya memenangi sokongan dan keyakinan orang bukan Melayu, mengelakkan Orang Asli daripada dieksploitasi oleh pengganas komunis dengan mewujudkan kawasan penempatan semula dan jungle fort untuk Orang Asli, memperkenalkan konsep Kawasan Putih agar penduduk berusaha menjadikan kawasan mereka bebas daripada kegiatan komunis dan mengedarkan berbagai risalah untuk menyeru penduduk memberi maklumat tentang kegiatan komunis serta memujuk komunis menyerah diri. Langkah kerajaan ini melibatkan kos yang tinggi. Dijangkakan bahawa darurat menelan kos antara $\$ 250,000$ hingga $\$ 300,000$ sehari sejak penghujung tahun 1948. Dengan itu, kerajaan terpaksa membelanjakan lebih $\$ 10$ juta sebulan atau $\$ 120$ juta setahun untuk tujuan menentang komunis. ${ }^{16}$ Menurut akhbar Straits Echo \& Times of Malaya bertarikh 3 Ogos 1950, kos darurat meningkat kepada $\$ 400,000$ sehari pada tahun $1950 .{ }^{17}$ Jumlah perbelanjaan untuk pertahanan, polis dan darurat pada tahun 1948 adalah $\$ 82$ juta yang berikutnya meningkat kepada $\$ 296$ juta pada tahun 1953. ${ }^{18}$ Keadaan ini menimbulkan kerisauan kerajaan British di Tanah Melayu. Pesuruhjaya Tinggi British Henry Gurney pernah membuat komen kepada Majlis Perundangan Persekutuan bahawa "the solution of our difficulties and our future development in all fields is going to be concerned very closely with finance."' Kerisauan ini timbul memandangkan untuk memulihkan industri getah dan timah akibat kerosakan pada masa Perang Dunia Kedua dibataskan oleh kekurangan modal. Pengeluaran getah dan timah juga dihadkan oleh gangguan yang disebabkan oleh undang-undang darurat seperti perintah berkurung menyekat penorehan pokok getah dan perlombongan timah serta pergerakan pekerja. Begitu juga, penoreh dan pelombong berasa takut untuk keluar bekerja kerana bimbang terdedah kepada keganasan komunis. Dengan itu, hasil pendapatan kerajaan Tanah Melayu dari dua komoditi utama tersebut telah terjejas. 
Bagaimanapun, Perang Korea yang meletus pada tahun 1950 telah mengubah keadaan ini. Perang Korea telah menyebabkan peningkatan permintaan ke atas getah dan timah untuk pembuatan peralatan perang. Ini berikutnya membawa kepada peningkatan harga getah dan timah. Kenaikan harga dua komoditi eksport utama Tanah Melayu ini membawa kepada peningkatan dalam hasil kerajaan melalui duti eksport getah dan timah. Keadaan ini seterusnya dapat membantu usaha kerajaan dalam menentang pengganasan komunis di Tanah Melayu. Sekaligus ia juga dapat meningkatkan keadaan hidup penduduk Tanah Melayu buat tempoh tersebut. Walaupun demikian, berikutan dengan berakhirnya Perang Korea pada Julai 1953, keadaan ekonomi di Tanah Melayu merosot. Harga getah dan timah mula menurun. Dengan itu, wujud masalah pengangguran di kalangan penduduk di Tanah Melayu, khasnya mereka yang bergantung kepada industri getah dan timah. Berdasarkan perangkaan Jabatan Buruh, seramai 16,573 pekerja menganggur pada November 1953. Kebanyakan mereka adalah pekerja lombong di Perak di mana 50 buah lombong ditutup kerana pengurangan permintaan berikutan dengan berakhirnya Perang Korea. ${ }^{20}$

\section{Peningkatan Hasil Kerajaan Tanah Melayu}

Akibat daripada Perang Korea, permintaan terhadap getah dan timah di Tanah Melayu telah meningkat. Jadual 1 menunjukkan jumlah pengeluaran getah di Tanah Melayu antara tahun 1948 hingga 1951. Pada tahun 1948, Tanah Melayu mengeluarkan sejumlah 994,818,730 kilogram $(979,107$ tan) getah dan 913,641,655 kilogram $(899,212$ tan) getah dihasilkan pada tahun 1949. Jumlah ini meningkat kepada $1,124,254,989$ kilogram $(1,106,499$ tan) pada tahun 1950 dan $1,173,805,570$ kilogram $(1,155,267$ tan) pada tahun 1951 berikutan dengan meletusnya Perang Korea. 
Jadual 1

Pengeluaran Getah di Tanah Melayu, 1948-1951 (tan)*

\begin{tabular}{|l|r|}
\hline Tahun & Jumlah \\
\hline 1948 & 979,107 \\
1949 & 899,212 \\
1950 & $1,106,499$ \\
1951 & $1,155,267$ \\
\hline
\end{tabular}

* Satu tan bersamaan dengan 1,016.047 kilogram.

Sumber: Malaya Rubber Statistics, dalam Fail Setiausaha Kerajaan Negeri Pulau Pinang, RCP/442/49, Rubber, Tea and Palm Oil Statistics etc. for $1948 / 49 / 50 / 51 / 52 / 53$.

Jadual 2 menunjukkan hasil pengeluaran timah di Tanah Melayu antara tahun 1947 hingga 1953. Berdasarkan jadual. Jelas menunjukkan Tanah Melayu mencatatkan hasil pengeluaran timah yang tinggi pada tahun-tahun berlakunya Perang Korea berbanding dengan tahun sebelumnya. Jumlah hasil pengeluaran timah berjumlah $58,648,264.93$ kilogram $(57,722$ tan) pada tahun 1950, 58,374,948.29 kilogram (57,453 tan) pada tahun $1951,58,619,815.62$ kilogram (57,694 tan) pada tahun 1952 dan 57,572,271.16 kilogram (56,663 $\tan )$ pada tahun 1953 berbanding dengan 27,359,097.57 kilogram $(26,927$ tan) pada tahun $1947,46,472,973.73$ kilogram $(45,739$ tan $)$ pada tahun 1948 dan 56,338,790.1 kilogram (55,449 tan) pada tahun 1949. 
Jadual 2

Pengeluaran Timah di Tanah Melayu, 1947-1953 (tan)*

\begin{tabular}{|l|l|}
\hline Tahun & Jumlah \\
\hline 1947 & 26,927 \\
1948 & 45,739 \\
1949 & 55,449 \\
1950 & 57,722 \\
1951 & 57,453 \\
1952 & 57,694 \\
1953 & 56,663 \\
\hline
\end{tabular}

* Satu tan bersamaan dengan 1,016.047 kilogram.

Sumber: Malaya Tin Statistics, dalam Fail Setiausaha Kerajaan Negeri Selangor, Sel. Sec. 411/1949, Malayan Tin Statistics, 1949, 1950 and 1951.

Bagaimanapun, pengeluaran bijih timah di Tanah Melayu tidak meningkat dengan ketara dalam tempoh Perang Korea walaupun terdapat permintaan yang tinggi terhadap bijih timah. Ini kerana usaha membuka kawasan lombong baru yang berpotensi untuk pengeluaran bijih timah tidak dapat dilakukan disebabkan gangguan akibat aktiviti komunis.

Permintaan yang tinggi terhadap getah dan timah seterusnya menyebabkan kenaikan harga getah dan timah. Harga getah meningkat kepada 169.55 sen bagi 0.4536 kilogram (sepaun) di pasaran Singapura pada tahun 1951, iaitu lebih empat kali ganda daripada harga tahun 1949. Harga pasaran timah pada tahun 1951 ialah $\$ 526.58$ bagi 60.48 kilogram (sepikul), iaitu meningkat hampir dua kali ganda daripada harga pada tahun 1949.21 Peningkatan harga komoditi getah dan timah telah meningkatkan hasil kerajaan melalui duti eksport yang dikenakan. Hasil kerajaan daripada duti eksport getah pada tahun 1949 ialah $\$ 28.1$ juta, meningkat kepada $\$ 89.3$ juta pada tahun 1950 dan $\$ 214.1$ juta pada tahun 1951. Begitu juga hasil kerajaan melalui duti eksport timah meningkat daripada $\$ 31.3$ juta pada tahun 1949 kepada $\$ 50.9$ juta 
pada tahun 1950 dan $\$ 76.2$ juta pada tahun 1951. Ini jelas bahawa kemakmuran negara akibat peningkatan permintaan getah dan timah pada zaman Perang Korea. Namun begitu, hasil kerajaan daripada duti eksport getah dan timah kemudian jatuh mendadak menjelang akhir Perang Korea. Misalnya, hasil daripada duti eksport getah berkurangan dari $\$ 110.8$ juta pada tahun 1952 kepada $\$ 54.7$ juta pada tahun 1953 dan $\$ 52.6$ juta pada tahun 1954. Hasil daripada duti eksport timah menurun dari $\$ 69.6$ juta pada tahun 1952 kepada $\$ 51.3$ juta pada tahun 1953 dan $\$ 52.7$ juta pada tahun 1954 . Keadaan tersebut dapat dilihat dalam Jadual 3.

Jadual 3

Hasil Kerajaan Melalui Duti Eksport Getah dan Timah, 1949-1954

(\$ juta)

\begin{tabular}{|l|r|c|}
\hline Tahun & Getah & Timah \\
\hline 1949 & 28.1 & 31.1 \\
1950 & 89.3 & 50.9 \\
1951 & 214.1 & 76.2 \\
1952 & 110.8 & 69.6 \\
1953 & 54.7 & 51.3 \\
1954 & 52.6 & 52.7 \\
\hline
\end{tabular}

Sumber: Ubahsuaikan daripada International Tin Study Group Statistical Year Book, 1956, London, 1957.

Berdasarkan jadual di atas jelas menunjukkan bahawa Perang Korea mempengaruhi hasil pendapatan kerajaan Tanah Melayu yang diperolehi melalui duti eksport dua komoditi utamanya, iaitu getah dan timah.

Dalam pada itu, hasil pendapatan kerajaan keseluruhan (dari dua komoditi di atas campur dengan punca lain seperti cukai pendapatan) meningkat dari $\$ 235.5$ juta pada tahun $1948, \$ 345.2$ juta pada tahun $1949, \$ 443.4$ juta pada tahun 1950 kepada $\$ 735.4$ juta pada tahun 1951 dan $\$ 725.1$ juta pada tahun 1952 sebelum menurun kepada 
\$620.2 juta pada tahun 1953 dan $\$ 622.2$ juta pada tahun 1954 sebagaimana yang ditunjukkan dalam Jadual 4. Berdasarkan jadual jelas bahawa kesan daripada Perang Korea telah berjaya menambahkan hasil pendapatan kerajaan Tanah Melayu, khasnya antara tahun 19501952. Terdapat lebihan hasil kerajaan antara tahun 1950 hingga 1952, iaitu sebanyak $\$ 103.4$ juta pada tahun $1950, \$ 186.7$ juta pada tahun 1951 dan \$52.9 juta pada tahun 1952. Sementara itu, Tanah Melayu mengalami defisit dalam pendapatan pada tahun 1948 ( $\$ 55.3$ juta), 1949 (-\$2.1 juta), 1953 ( $\$ 170.2$ juta) dan 1954 ( $\$ 91.8$ juta).

Jadual 4

Pendapatan dan Perbelanjaan Kerajaan Tanah Melayu, 1948-1954

(\$ juta)

\begin{tabular}{|c|c|c|c|}
\hline Tahun & Jumlah Pendapatan & Jumlah Perbelanjaan & Lebihan/Kurangan \\
\hline 1948 & 235.5 & 290.8 & -55.3 \\
1949 & 345.2 & 347.3 & -2.1 \\
1950 & 443.4 & 340.0 & +103.4 \\
1951 & 735.4 & 548.7 & +186.7 \\
1952 & 725.1 & 672.2 & +52.9 \\
1953 & 620.2 & 790.4 & -170.2 \\
1954 & 622.2 & 714.0 & -91.8 \\
\hline
\end{tabular}

Sumber: Foo Chee Hui, "The Failure of The Communist Insurrection In Malaya Between 1948 and 1960', Long Essay (Kursus AE300), Jabatan Sejarah, Universiti Malaya, 1979/80, hlm. 31.

Kemakmuran ekonomi Tanah Melayu yang dicetuskan oleh Perang Korea itu dapat membantu kerajaan membiayai sebahagian daripada kos darurat di Tanah Melayu. Dengan adanya peningkatan dalam hasil pendapatan kerajaan Tanah Melayu, langkah-langkah yang diambil untuk membanteras pengganasan komunis dapat digerakkan dengan lebih giat dan lancar agar keamanan dapat dipulihkan di Tanah
Melayu secepat mungkin. 


\section{Mempergiatkan Usaha Kerajaan Dalam Menangani Pengganas Komunis}

Peningkatan dalam hasil kerajaan kemudian disalurkan untuk membiayai kos darurat yang semakin meningkat. Antaranya, memperbesarkan pasukan keselamatan di Tanah Melayu. Pada akhir tahun 1952, kekuatan tentera di Tanah Melayu mencapai angka 28,000 orang anggota berbanding dengan permulaan darurat hanya 11,500 orang. Pada masa yang sama, pasukan polis berjumlah 26,154 orang dan polis khas berjumlah lebih kurang 99,000 orang. Unit Home Guard mencapai angka 200,000 orang. Pada permulaan zaman darurat di Tanah Melayu hanya terdapat 10,000 orang polis. ${ }^{22}$ Elaun pasukan keselamatan dan kemudahan dapat disediakan oleh pihak kerajaan adalah hasil daripada sebahagian lebihan pendapatan yang diperolehi pada zaman harga getah dan timah melambung berikutan dengan meletusnya Perang Korea. Sebagai contohnya, jumlah yang dibelanjakan oleh kerajaan ke atas pasukan polis meningkat daripada $\$ 69$ juta pada tahun 1949 kepada $\$ 73.5$ juta pada tahun 1950 dan seterusnya $\$ 138.4$ juta pada tahun 1951. Begitu juga peruntukan perbelanjaan kerajaan ke atas operasi-operasi darurat bertambah dari $\$ 82$ juta pada tahun 1949 kepada $\$ 101$ juta pada tahun 1950 dan seterusnya $\$ 217$ juta pada tahun $1951 . .^{23}$

Pada masa yang sama, rancangan penempatan semula yang bertujuan untuk memisahkan penduduk, khasnya setinggan daripada pengganas komunis dan memutuskan bantuan penduduk kepada komunis dapat dilancarkan dengan lebih pantas. Pada tahun 1948, cuma 10,000 penduduk yang ditempatkan semula di bawah rancangan ini. Angka ini meningkat kepada 20,000 pada tahun 1949. Berdasarkan hasil yang diperolehi daripada kenaikan harga getah dan timah, kerajaan mampu mengatur pemindahan seramai lebih kurang 85,000 penduduk pada tahun 1950 dan lebih kurang 230,000 orang pada tahun $1951 .^{24}$ $\mathrm{P}_{\mathrm{ada}}$ akhir tahun 1951 , lebih $\$ 40$ juta telah dibelanjakan ke atas tancangan penempatan semula berbanding dengan kurang daripada $\$ 2$ juta yang diperuntukkan untuk tujuan yang sama sebelum tahun 1950.25 Pada tahun 1952, kerajaan memperuntukkan lagi $\mathbf{\$} 30$ juta untuk kos penempatan dan pengumpulan semula. Untuk melicinkan 
perlaksanaan rancangan penempatan semula, 85 orang penyelia penempatan semula dan 333 orang penolong penyelia penempatan semula dilantik pada tahun $1952 .{ }^{26}$ Dengan itu, hasil lebihan kerajaan yang diperolehi daripada zaman harga getah dan timah melambung akibat Perang Korea menjadi alat penting dalam menjayakan rancangan penempatan semula di Tanah Melayu. Rancangan penempatan semula pula merupakan antara langkah kerajaan yang paling berkesan dalam melemahkan gerakan komunis di Tanah Melayu. Ini kerana kesan daripada perlaksanaan rancangan ini, pihak komunis mengalami masalah bekalan makanan, wang dan maklumat di mana hubungan penduduk dengan pengganas komunis telah diputuskan di bawah rancangan penempatan semula ini.

Selain itu, kekuatan kewangan kerajaan juga membolehkan kerajaan membiayai strategi hearts and minds yang dicadangkan oleh Jeneral Templer. Dasar ini bertujuan untuk menawan hati dan fikiran penduduk supaya menyokong kerajaan dan bukan komunis. Antaranya, mengedarkan safe-conduct passes untuk menyeru pengganas komunis menyerah diri dengan jaminan akan memberi layanan baik kepada mereka. Contohnya, seramai 23 orang pengganas komunis menyerah diri kepada pihak berkuasa antara Jun hingga September 1953 di Pahang kesan daripada pas menyerah diri yang diedarkan itu. ${ }^{27}$ Begitu juga Templer menggunakan cara voice-aircraft untuk menarik perhatian pengganas komunis menyerah diri kepada kerajaan setelah mendengar seruan rakan-rakan mereka yang telah menyerah diri dan pujukan daripada ahli keluarga pengganas berkenaan. Sumber kewangan yang ada pada kerajaan itu membolehkan sejumlah 20 juta risalah menyeru pengganas komunis menyerah diri dicetak dan diedarkan di kawasan yang menjadi tumpuan pengganas komunis di Tanah Melayu pada tahun $1953 .{ }^{28}$ Selain itu, Jeneral Templer menawarkan hadiah wang tunai yang lumayan kepada orang ramai yang memberi maklumat sehingga seseorang pengganas komunis itu ditangkap atau dibunuh. Maklumat tentang Chin Peng, misalnya, bernilai $\$ 250,000$. Manakala maklumat berkaitan ahli jawatankuasa dan ahli biasa Parti Komunis Malaya (PKM) bernilai antara $\$ 200,000$ hingga $\$ 2,500$. Tindakan kerajaan ini akhirnya berjaya melemahkan semangat pengganas komunis dan gerakan komunis. Kejayaan seterusnya dicapai oleh Tanah 
Melayu setelah negara memperolehi kemerdekaan daripada pihak British pada 31 Ogos 1957 dan akhirnya darurat diisytiharkan tamat pada 31 Julai 1960.

\section{Meningkatkan Taraf Hidup Penduduk}

Hasil lebihan yang dikumpulkan oleh kerajaan semasa zaman kemakmuran ekonomi yang dicetuskan oleh Perang Korea juga disalurkan untuk mengembangkan kemudahan sosial bagi penduduk Tanah Melayu. Kemudahan ini bukan sahaja dapat memperbaiki keadaan hidup penduduk, sekaligus ia juga dapat meningkatkan keyakinan penduduk kepada kerajaan. Dengan adanya keyakinan dan sokongan penduduk kepada kerajaan, kempen menentang komunis yang sedang dijalankan oleh kerajaan akan lebih berjaya. Perkhidmatan sosial seperti pendidikan, kesihatan dan kemudahan infrastruktur seperti jalan raya, bekalan air dan elektrik dapat diperluaskan sehingga ke kawasan luar bandar. Begitu juga, wang yang diperuntukkan oleh kerajaan Persekutuan untuk mengembangkan pendidikan penduduk telah meningkat dari $\$ 2.7$ juta pada tahun 1949 kepada $\$ 14.2$ juta pada tahun $1952 .{ }^{29}$ Selain itu, peruntukan untuk projek-projek kerja awam meningkat dari $\$ 11.8$ juta pada tahun 1949 kepada $\$ 13.9$ juta pada tahun $1950, \$ 34.3$ juta pada tahun 1951 sehingga $\$ 51.9$ juta pada tahun $1953 .{ }^{30}$ Dalam aspek kemudahan kesihatan, misalnya, kerajaan mampu menyediakan 150 dispensari statik, 73 dispensari bergerak dan 94 pusat kebajikan bayi untuk berkhidmat kepada penduduk luar bandar di seluruh Tanah Melayu pada tahun 1952. ${ }^{31}$ Dengan itu, taraf kesihatan penduduk Tanah Melayu semakin baik. Kadar kematian penduduk Tanah Melayu menurun daripada 14.2 per seribu pada tahun 1949, 15.8 per seribu pada tahun 1950 dan 15.3 per seribu pada tahun 1951 kepada 13.6 per seribu pada tahun $1952 .{ }^{32}$ Dengan adanya zaman harga getah dan timah melambung akibat Perang Korea, sehingga tahun 1954 sepanjang lebih kurang 10,225.77 kilometer (6,354 batu) jalan dibina di Tanah Melayu. ${ }^{33}$ Selain itu, zaman

Thelambung ini telah membolehkan pihak berkuasa memperluaskan kemudahan pengairan dan perparitan untuk kesenangan hidup penduduk Tanah Melayu. Pada tahun 1952, kemudahan pengairan dan 
perparitan diperluaskan meliputi lebih 80,938 hektar (200,000 ekar) kawasan penanaman padi sawah. Pada masa yang sama, kira-kira 16,187.6 hektar (40,000 ekar) tanah hutan baru dibuka dan dibangunkan. Ketika musim padi 1952/53, Tanah Mclayu mampu menghasilkan lebih kurang 448,076,727 kilogram (441,000 tan) padi. ${ }^{34}$ Dalam pada itu, sehingga tahun 1950, kerajaan mampu menyediakan 87 skim bekalan air paip di Tanah Melayu. Skim terbesar adalah di Kuala Lumpur yang membekalkan air kepada kira-kira 230,000 penduduk. Manakala skim yang kedua besar ialah di Lembah Kinta, Perak yang menyediakan air untuk 117,000 penduduk, termasuk penghuni di bandar Ipoh. ${ }^{35}$ Keadaan ini terus berkembang sehingga tahun 1951, sudah ada 97 skim bekalan air paip di Tanah Melayu. Angka ini seterusnya meningkat kepada 103 pada tahun $1952 .{ }^{36}$ Dengan adanya kemakmuran industri getah dan timah telah mampu meningkatkan pendapatan kerajaan dan membolehkannya menyediakan kemudahan asas tersebut. Kemudahan asas itu penting bukan sahaja untuk kesenangan hidup penduduk Tanah Melayu tetapi juga untuk memenangi sokongan mereka. Kemudahan asas itu turut melahirkan perasaan kesetiaan penduduk kepada pihak kerajaan apabila kerajaan mengambil perhatian terhadap keadaan hidup mereka.

Kesan Perang Korea bukan semata-mata memberi kesan besar kepada sumber kerajaan sahaja, ia juga membawa kemakmuran kepada semua penduduk Tanah Melayu. Kemakmuran ekonomi Tanah Melayu akibat Perang Korea juga mewujudkan lebih banyak peluang pekerjaan kepada penduduk Tanah Melayu, khasnya dalam industri getah dan timah. Dengan demikian dapat mengelakkan mereka daripada menyertai pengganas komunis. Upah tinggi dalam industri getah dan timah mengurangkan perhatian mereka kepada kegiatan komunis. Keadaan ini sekaligus mengurangkan kesusahan dan kemarahan penduduk akibat daripada langkah pemindahan dan penempatan semula penduduk luar bandar di kawasan yang ditetapkan. Pemindahan penduduk, khasnya penduduk luar bandar dan setinggan menimbulkan masalah pekerjaan kerana dalam proses pemindahan penduduk terpaksa meninggalkan tanah, tanaman dan ternakan mereka. Kehidupan di kawasan baru pula dikongkong oleh berbagai peraturan darurat yang dikenakan oleh pihak berkuasa seperti perintah berkurung 
dan pemeriksaan yang kerap oleh pasukan keselamatan. Tambahan pula, kebanyakan kawasan penempatan semula tidak disediakan tanah rang sesuai untuk aktiviti penanaman. Keadaan ini berubah apabila meletusnya Perang Korea di mana peluang kerja wujud terutama dalam industri getah dan timah.

Dengan meningkatnya permintaan terhadap getah, terdapat peningkatan dalam kawasan penanaman getah dan permintaan untuk penoreh getah juga meningkat. Jadual 5 menunjukkan keluasan kawasan penanaman getah di Tanah Melayu di antara tahun 1947 hingga tahun 1953. Berdasarkan jadual jelas bahawa terdapat peningkatan dalam keluasan penanaman getah pada zaman Perang Korea, khasnya antara tahun 1951 hingga 1953 berbanding dengan tahun-tahun sebelumnya. Jumlah keluasan kawasan tanaman getah adalah 1,430,668.58 hektar $(3,535,221$ ekar) pada tahun 1951, 1,462,072.17 hektar $(3,612,820$ ekar) pada tahun 1952 dan 1,508,498.16 hektar (3,727,540 ekar) pada tahun 1953 berbanding dengan 1,342,477.73 hektar (3,317,299 ekar) pada tahun 1947, 1,360,780.24 hektar (3,362,525 ekar) pada tahun

Jadual 5

Kawasan Pengeluaran Getah di Tanah Melayu, 1947-1953 (ekar)*

\begin{tabular}{|c|c|c|c|}
\hline Tahun & Estet & Kebun Kecil & Jumlah \\
\hline 1947 & $1,934,106$ & $1,383,193$ & $3,317,299$ \\
1948 & $1,952,347$ & $1,410,198$ & $3,362,525$ \\
1949 & $1,970,579$ & $1,393,881$ & $3,364,460$ \\
1950 & $1,964,370$ & $1,393,881$ & $3,358,251$ \\
1951 & $1,963,735$ & $1,571,486$ & $3,535,221$ \\
1952 & $1,996,727$ & $1,616,093$ & $3,612,820$ \\
1953 & $2,029,706$ & $1,697,834$ & $3,727,540$ \\
\hline
\end{tabular}

* Satu ekar bersamaan dengan 0.40469 hektar.

Sumber: Rubber Statistics Handbook, 1953, (Acreage, Production, Imports, Exports and Consumption), Kuala Lumpur: The Department of Statistics, Federation of Malaya, 1954, hlm. 3. 
$1948,1,361,563.32$ hektar $(3,364,460$ ekar $)$ pada tahun 1949 dan 1,359,050.60 hektar (3,358,251 ekar) pada tahun 1950 .

Akibat daripada peningkatan permintaan terhadap tenaga buruh, gaji pekerja dan penoreh juga meningkat. Pekerja tidak mahir dalam industri getah yang mendapat 20 hingga 25 sen bertambah kepada $\$ 1.43$ sehari pada suku pertama tahun 1950 dan $\$ 2.90$ sehari pada suku kedua tahun 1951. Malahan seorang penoreh getah bergaji harian boleh memperolehi bayaran sejumlah $\$ 3.65$ sehari pada April hingga Jun 1951. Begitu juga di sesetengah kebun getah, sistem bahagi dua membawa keuntungan yang lebih tinggi kepada penoreh dan kadangkala mereka dapat memperolehi sehingga $70 \%$ daripada keuntungan pengeluaran. ${ }^{37}$ Pada masa yang sama, industri timah berkembang di Tanah Melayu. Pada akhir tahun 1950, sebanyak 41 lombong dibuka semula atau mula beroperasi. Selain itu, tujuh lombong lain dibuka pada tahun $1951 .{ }^{38}$ Perkembangan ini turut meningkatkan peluang kerja di lombong-lombong timah. Gaji pekerja lombong naik mengikut kenaikan harga timah di pasaran. Berikutan dengan kenaikan gaji kepada pekerja industri getah dan timah, majikan industri lain terpaksa menaikkan gaji pekerja mereka supaya menghalang pekerja meninggalkan perkhidmatan mereka. ${ }^{39}$ Dengan itu, tanda-tanda kemakmuran wujud akibat kenaikan harga getah dan timah yang dicetuskan oleh Perang Korea. Pemilik kebun kecil getah antara lebih kurang 2.02 hektar hingga 4.04 hektar (lima hingga 10 ekar) mampu memperolehi pendapatan yang lumayan. Malahan sesetengah daripada mereka dikatakan mampu memandu kereta untuk mengumpul susu getah. Radio dan basikal dapat dilihat di kebanyakan pusat penempatan semula. Dalam erti kata lain, kehidupan penduduk Tanah Melayu bertambah baik akibat kemakmuran ekonomi yang dibawa oleh Perang Korea walaupun darurat di Tanah Melayu masih berlanjutan. Keadaan tersebut pernah dinyatakan oleh seorang pemerhati Eropah:

... by far the most important event in recent years in their eyes is not the Emergency but the Korean War which produced a wave of prosperity in Malaya such as it had not known since $1940 .^{+0}$ 
Peningkatan hasil pengeluaran industri getah dan timah turut membolehkan pihak pengurusan estet dan lombong memperkuatkan aspek pertahanan demi keselamatan pekerja. Misalnya, pihak pengurusan mampu mengumpulkan semula para pekerja dalam kawasan yang dipertahankan. Ini dianggarkan melibatkan kira-kira 650,000 orang, iaitu 510,000 di estet, 80,000 di lombong bijih timah dan 60,000 di kawasan penempatan semula pada tahun 1951. Langkah ini dapat mengelakkan para pekerja terdedah kepada ancaman komunis. Ia juga menyukarkan pengganas komunis mempergunakan para pekerja untuk kepentingan mereka. Untuk tujuan keselamatan para pekerja tersebut, bagi estet yang dimilik oleh orang Eropah, pihak pengurusannya telah membelanjakan $\$ 16$ juta untuk aspek pertahanan pada tahun 1951 berbanding dengan $\$ 4$ juta pada tahun 1949.41

Dengan itu, kemakmuran ekonomi di Tanah Melayu kesan Perang Korea telah meningkatkan keadaan hidup penduduk dan mengembalikan keyakinan penduduk terhadap masa depan ekonomi serta politik negara.

\section{Kesimpulan}

Perang Korea berlaku pada masa yang tepat bagi kerajaan British di Tanah Melayu. Perang Korea telah mencetuskan satu zaman kemakmuran ekonomi di Tanah Melayu, khasnya bagi industri getah dan timah. Keadaan tersebut telah melipatgandakan hasil kerajaan melalui duti eksport komoditi getah dan timah, menyediakan peluang pekerjaan kepada penduduk Tanah Melayu, menawarkan upah yang lebih tinggi, memperbaiki keadaan hidup penduduk dan yang penting sekali membolehkan usaha kerajaan membanteras komunis dijalankan dengan giat. Walaupun Perang Korea hanya mengambil masa tiga tahun, namun kesannya terhadap ekonomi dan langkah kerajaan menentang komunis tidak boleh diperkecilkan peranannya. Ia membantu kerajaan merealisasikan tindakan yang menyeluruh dalam menghapuskan pengganas komunis, yang melibatkan tentera, polis dan orang awam. Semua langkah ini menelan perbelanjaan yang tinggi. Sungguhpun, keadaan ekonomi Tanah Melayu selepas Perang Korea tidak secerah seperti sebelumnya, namun zaman yang paling sukar dalam menghadapi 
komunis telah berakhir di mana kerajaan berada di pihak yang melancarkan serangan dan kini komunis semakin lemah. Bagaimanapun, perlu diketahui bukan sahaja kesan Perang Korea yang mentumbangkan kepada kejayaan dalam kempen kerajaan menentang komuns. Namun begitu, tidak dapat dinafikan zaman itu penting dalam membantu kerajaan dalam menewaskan pengganas komunis. Tanpa kenaikan harga getah dan timah kemungkinan pihak kerajaan akan menghadapi kesukaran dalam menangani pengganas komunis kerana masalah kewangan. Dengan itu, usaha melemahkan gerakan komunis di Tanah Melaru akan mengambil masa yang lebih panjang lagi. Dalam kata lain, Perang Korea telah menyelesaikan banyak masalah yang dihadapi oleh kerajaan British di Tanah Melayu pada masa itu yang sedang berdepan dengan suasana kacau bilau akibat kegiatan komunis. Perang Korea yang meletus pada tahun 1950 memberi peluang yang cukup luas untuk pihak kerajaan memulihkan ekonomi dan juga membangunkan kemudahan sosial buat sementara untuk Tanah Melașu. 


\section{Nota}

Richard Stubbs, Counter-Insurgency and The Economic Factor: The Impact of of Southeast Asia Studies, February 1974, hlm. 1. Dinasti Yi (1392-1910) diasaskan oleh Jener. Y 1392. Sebelumnya Koreà adalah di bawah Keral Yi Sung-ge pada tahun yang kemudian dijatuhkan oleh Jeneral Yi Kerajaan Koryu (918-1392) Dinasti Yi berakhir apabila Perdana Menteri, Yi kabinetnya tunduk kepada imperialisme Jepun pada tahun 1910 Maklumat lanjut tentang Kerajaan Koryu dan Dinasti Yi, sila lihat Harold W. Sunoo, Korea: A Political History in Modern Times, Columbia: KoreanAmerican Cultural Foundation, tiada tahun, hlm. 34-45.

Berdasarkan Japanese Police Reportpada tahun 1935, Kim II-sung dikatakan sebagai ketua Tentera Gerila Komunis Cina yang dibentuk di Korea Utara pada 19 September 1933. Beliau mengambil bahagian dalam aktiviti anti-Jepun pada tahun 1930-an. Dengan meletusnya Perang Dunia Kedua pada tahun 1941, beliau menyembunyikan diri di Rusia dan meneruskan gerakan bawah tanah menentang Jepun. Beliau kembali ke Korea Utara pada Ogos 1945 selepas Jepun menyerah kalah dengan nama Kim Yung Hwan. Pada 14 Oktober 1945, beliau muncul di Pyongyang sebagai Jeneral Kim II-sung. Pada Oktober 1945, beliau dilantik sebagai setiausaha pertama Parti Komunis cawangan Korea Utara. Dengan bermulanya rejim komunis di Korea Utara di bawah kawalan Rusia, beliau berjaya memperolehi kekuasaan dan menegakkan kedudukan sebagai pemimpin kerajaan baru di Korea Utara. M.P. Srivastava, D. Litt, The Korean Conflict: Search for Unification, New Delhi: Prentice Hall of India Private Limited, 1982, hlm. 10-11 dan 23. Pentadbiran Korea Utara di bawah Kim II-sung, lihat Harold W. Sunoo, Korea: A Political History in Modern Times, hlm. 310-313. David Rees, The New Pressures From North Korea, London: Institute for the Study of Conflict, 1970, hlm. 1; M.P. Srivastava, D. Litt, The Korean Conflict: Search for Unification, hlm. 17-33. Lihat juga Tim Carew, The Korean War: The Story of the Fighting Commonwealth Regiments 1950-1953, London: Pan Books Ltd., 1970, hlm. 16-19. M.P. Srivastava, D. Litt, The Korean Conflict. Search for Unification, hlm. 4344. Keterangan lanjut tentang kronologi Perang Korea, sila lihat Tim Carew, The Korean War: The Story of the Fighting Commonwealth Regiments 1950-1953, hlm. 299-303. 
6 Berikutan dengan pembunuhan tiga peladang Eropah (Arthur Walker, pengurus Ladang Elphil; John Allison dan pembantunya, Ian Christian dari Estet Phin Soon) di Sungai Siput, Perak pada 16 Jun 1948, darurat diisytiharkan di beberapa kawasan di Perak dan Johor pada petang 16 Jun 1948. Pada hari keesokannya, undang-undang itu diperluaskan sehingga meliputi seluruh negeri Perak dan Johor. Pada 18 Jun 1948, undang-undang darurat dilanjutkan ke seluruh Tanah Melayu. Untuk pengisytiharan darurat di Tanah Melayu, lihat The Straits Times, 18 June 1948, hlm. 1; The Malaya Tribune (Singapore), 19 June 1948, hlm. 2; The Malay Mail, 18 June 1948, hlm. 4; Utusan Melayu, 18 Jun 1948, hlm. 1; Majlis, 18 June 1948, hlm. 1; The China Press, 19 June 1948, hlm. 5; Nanyang Siang Pau, 19 June 1948, hlm. 7. Lihat juga Memorandum of The Situation In Malaya, dalam C.O. 717/210/52849/3, Law and Order, hlm. 118; A Paper on The Dimensions and Nature of The Security Problem Confronting The Government of The Federation of Malaya, 16 September 1948, dalam C.O. 717/177/52849/41, Law and Order, The Squatter Problem, hlm. 116-117. The Straits Times, 24 February 1949, hlm. 1; Indian Daily Mail, 26 March 1949, hlm. 6; 28 March 1949, hlm. 4. The Straits Times, 21 December 1950, hlm. 7. Lihat juga SP. 13/A/6, The Malayan Constitutional Proposals, hlm. 1. The Straits Times, 24 July 1952, hlm. 7.

Federation of Malaya Political Report No. 12 For December 1950, hlm. 6, dalam C.O. 825/82/1/55404/3, Political Intelligence Reports, Federation of Malaya. The China Press, 5 January 1951, hlm. 3. Nanyang Siang Pau, 22 September 1948, hlm. 1.

Nicholas J. White, Business, Government, and the End of Empire: Malaya 19411957, Kuala Lumpur: Oxford University Press, 1996, hlm. 99. Press, 1950, hlm. 204. Sulaiman bin Haji Abdul Samad, "Bulan Rakyat Melawan Penjahat", dalam Prof. Khoo Kay Kim dan Adnan Hj. Nawang (penyunting), Darurat 1948-1960, Kuala Lumpur: Muzium Angkatan Tentera, 1984,
hlm. 155 .

Federation of Malaya Annual Report 1949, hlm 208; Richard Stubbs, CounterInsurgency and the Economic Facur: The Impact of The Korean Whar Prices Boom on The Malayan Emergency, hlm. 7; Cheah Boon Kheng, "Some Aspects 

of The Malayan Emergency: 1948-1960", dalam Khoo Kay Kim (ed.),
The Historyof South-East, South and East Asia: Essays and Documents, Kuala
Lumpur: Oxford University Press, 1977, hlm Budget, March 1949, dalty Press, 1977, hlm. 113; Extract from Straits Additional Expenditure Due T. 717/176/52849/34, Law and Order, tract from Straits Budget, 20 January 194 ency, hlm. 134. Lihat juga Ex34, Law and Order, Additional Expenditalam C.O. 717/176/52849/ 235; Colonial Office Malaya, 11 th-17th 178/52849/62, Law and Order, Webruary 1949, dalam C.O. 717/ Eastern Department (Coperts Prepared in No. 181, dalam Fail Setiausaha Kerajaan Negeri Ke Emergency Leaflets.

Straits Echo \& Times of Malaya, 3 August 1950, hlm. 4. Lihat juga Sin Chew Jit Poh, 1 January 1953, hlm. 17.

Cheah Boon Kheng, "Some Aspects of The Malayan Emergency: 19481960", hlm. 113.

Richard Stubbs, Hearts and Minds in Guerrilla Warfare: The Malayan Emergency 1948-1960, Singapore: Oxford University Press, 1989, hlm. 108.

The China Press, 30 December 1953, hlm. 5; Sin Chew Jit Poh, 31

December 1953, hlm. 8. Lihat juga T.N. Harper, The End of Empire and The Making of Malaya, Cambridge: Cambridge University Press, 1999, hlm. 203; Anthony Short, In Pursuit of Mountain Rats: The Communist Insurrection in Malaya, Singapore: Cultured Lotus, 2000, hlm. 348-349.

Richard Stubbs, Counter-Insurgency and The Economic Factor: The Impact of The Korean War Prices Boom on The Malayan Emergency, hlm 10-14.

Ramli bin Haji Ahmad, "Perjumpaan Baling 1955", dalam Prof. Khoo Kay Kim dan Adnan Hj. Nawang (penyunting), Darurat 1948-1960, Kuala Lumpur: Muzium Angkatan Tentera, 1984, hlm. 195.

Richard Stubbs, Counter-Insurgency and the Economic Factor. The Impact of The Korean War Prices Boom on The Malayan Emergency, hlm. 12-18; Richard Stubbs, Hearts and Minds in Guerrilla Warfare, hlm. 109. Guerrilla Warfare, hlm. 109-110.

Federation of Malaya Annual Report 1952, Kuala Lumpur: Government Press, 1953, hlm. 14. 
Anthony Short, In Pursuit of Mountain Rats: The Communist Insurrection in Malaya, hlm. 422.

$2 R$

Ismail bin Saad, "Pemberontakan PKM: Mengapa Gagal?", dalam Prof. Khoo Kay Kim dan Adnan Haji Nawang (penyunting), Darurat 1948 1960, Kuala Lumpur: Muzium Angkatan Tentera, 1984, hlm. 87.

2) Ibid., hlm. 15-18.

3) Ibid., hlm. 18. Lihat juga Richard Stubbs, Hearts and Minds in Guerrilla Warfare, him. 109-110.

Federation of Malaya Annual Report 1952, hlm. 178. Lihat juga Manchester Guardian, 26 June 1952, dalam C.O. 1022/29/SEA10/72/01, The Resettlement of Squatter In Malaya, hlm. 68.

Kadar kematian pada tahun 1949, lihat Straits Echo \& Times of Malaya, 17 November 1950, hlm. 6. Lihat juga Background Information and Material For Speakers-The Emergency and Anti-Bandit Month, Kuala Lumpur: Department of Public Relations, Federation of Malaya, 1950, hlm. 18; Malayan Bulletin, Vol. 5, No. 51, 25th March 1951, dalam C.O. 717/ 205/52932/1951, Association of British Malaya Monthly Bulletin, hlm. 64. Kadar kematian untuk tahun 1950 dan 1951, lihat Federation of Malaya Annual Report 1951, Kuala Lumpur: Government Press, 1952, hlm. 154-155. Kadar kematian untuk tahun 1952, lihat Federation of Malaya Annual Report 1952, hlm. 172.

Federation of Malaya Annual Report 1954, Kuala Lumpur: Government Press, 1955, hlm. 339; Federation of Malaya Annual Report of The Public Works Department For The Year 1954, Kuala Lumpur: The Government Press, 1956, hlm. 16.

Federation of Malaya Annual Report 1953, Kuala Lumpur: Government Press, 1954, hlm. 245-247. Lihat juga Information Paper No. 22, Report on Padi Production 1953, hlm. 1, dalam Fail Pejabat Parit dan Taliair Negeri Sembilan, D.I.D./N.S. 71/48, Miscellaneous Fuction and Policy of The Drainage and Irrigation Department. Federation of Malaya Annual Report 1950, Kuala Lumpur: Government Press, 1951, hlm. 173.

36 Keterangan untuk tahun 1951, lihat Federation of Malaya Annual Report 1951, hlm. 236. Maklumat untuk tahun 1952, lihat Federation of Malaya 
3

Richard Stubbs, Counter-Insurgency and The Economic Factor: The hlm. 34; Federation of Malaya Annual Report 1951 , halan Emergency, eration of Malaya Annual Report 1952, hlm. 37. Lim. 36; FedStubbs, Hearts and Minds in Guerilla Wh. 37. Lihat juga Richard

38 Federation of Malara

Hearts and Minds in Guerrill Weport 1950, hlm. 29. Lihat juga Richard Stubbs,

39. Federation of Malaya Annual Repare, hlm. 110.

Annual Report 1951, hlm. 36-37. L 1950, hlm. 32; Federation of Malaya Minds in Guerrilla Warfare, hlm. 111.

$+0$ J.B. Perry Robinson, Transformation in Malaya, London: Secker and Warburg, 1956, hlm. 103. Rujuk juga Richard Stubbs, Hearts and Minds
in Guerrilla Warfare, hlm. 111-112.

41 Richard Stubbs, Hearts and Minds 